\title{
The Influence of Physical Activity, Social Economy, and Family Environment toward Student's Social Skills
}

\author{
Misriandi ${ }^{1}$, Yufiarti ${ }^{2}$, Elindra Yetti $^{3}$ \\ \{Misriandi@yahoo.co.id ${ }^{1}$,yufiarti@unj.ac.id ${ }^{2}$, elindrayetti@unj.ac.id ${ }^{3}$ \} \\ Universitas Negeri Jakarta, Indonesia ${ }^{123}$
}

\begin{abstract}
This paper is aimed at examining the effect of physical activity, socioeconomic, and family environment on the social skills of elementary school students of South Tangerang City. In collecting the data, survey was employed as it used quantitative technique in which it examined how independent variable influenced the dependent one partially or simultaneously. Samples taken to assert this research are 164 students coming from $2^{\text {nd }}$ grade of Labschool FIP UMJ and $2^{\text {nd }}$ grade of Madrasah Pembangunan of UIN Jakarta. This study brings the writers to the facts that; (1) physical activities directly affect social skills; (2) socioeconomic effects directly on social skill; (3) family environment directly affects social skills; (4) physical, socio-economic and family activities all at once influence on students' social skills. For this reason, it is assumed that the students' social skills can be well fostered once they have well-developed quality of physical activities, socio-economic and family environment.
\end{abstract}

Keywords: Social Skill, Physical Activities; Social Economy, Family Environment.

\section{Introduction}

Social emotional development involves both relations and interactions among people through feelings expressed by someone towards others, whether it is happy or sad. [1] in his research mentioned the importance of the interaction for children"peer interactions play an important role for young children in learning new concepts and developing social behaviors in preschool years". Social emotional development is one of developmental aspects of children that need to be stimulated. This aspect plays a very influential role as it will determine how ones interact and treat their surrounding in the future life. In this case, social emotional development could be fostered then by children through physical activities that will enable them to work out, gain social behavior standard, and control their emotion.

Harmonious family does not always belong to its member's completeness which means the existence of a full parent- father and mother, as in many cases single parents are proven to be effective enough in helping children's psychological development. The most important thing a parent should note is to create a democratic atmosphere in the family so that teens can establish good communication with parents and siblings. To achieve this goal, reciprocal communication between children and parent need to be well established.

In line with the family environment, socioeconomic factors also matter on students' social skills development. Social factors related to ones' relations with humans, society and the environment they live. Then, economic factor refers to the conditions of a person that is 
strongly related to income, position, or occupation. Logically, the more members a father should grant, the higher the income he requires to cover all the needs of his family, and vice versa. According to [2] the socioeconomic status of parents is a combination of economic and social formed from one's experience at work, personal prestige, and economic factors in which indirectly relate to social positions, education, and employment status. Families having good socioeconomic status will certainly cover their children's needs and absolutely will give proper attention to their children's future life.

\section{Theoritical review}

\subsection{Social skills}

Social skills refer to a person's ability to interact with others. It also belongs to ones' ability to do proper actions that are acceptable to the environment [3]. In other definition, social skills are the ability to interact with other people through the ways that can be accepted or assessed appropriately in a social context. Simply, this interaction is mutually beneficial for those involved individuals. [4] that interpersonal behavior is a behavior that involves skills used during social interactions which is also named as friendship skills. Social skill is important to shape one's ability to their environment and avoid conflicts when they communicate both physically and verbally.

The socioeconomic status of a child's family also greatly influences the number and types of skills they learn. The skills of children coming from low socioeconomic levels are more focused in the field of helping skills which relate to independence and social, while children from the middle and high socioeconomic level are merely focused on the group of playing skills [5].

\subsection{Physical activities}

Physical activities refer to the limbs movement causing the expenditure of energy in which it is crucial for the maintenance of physical, mental, and quality of life in order to keep one to be healthy and fit throughout the day long. According to the Indonesian Ministry of Health, physical activity is very important to maintain physical health, mental health, and quality of life in order that ones can stay healthy and fit throughout the day. In addition, Dhias convincely proved that based on the dynamic balance chart of boys and girls starting from the age of seven years to the age of nine, boys are better balanced than girls [6].

\subsection{Socio-economic status of parents}

Society is made up of individuals who form heterogeneous communities and social classes. The existence of those various classes however establishes any layers and stratification among those individuals. As a consequence, each individuals in society plays any different roles, rights, jobs, behaviors, and treatments. Through the above mentioned definition, it can be said that social status refers to the situation that attributes someone in the society. Although every single individual has any different roles, they are however mutually interconnected even with the environment. This connectivity will foster balanced and continuous daily life. 


\subsection{Family environment}

A family is an innate thing ones would own physically and psychologically. It is the first and foremost place where a child starts to learn and to develop. As it is stated in the UN resolution that family is a motor for educating children, caring them for, and socializing children, developing the ability of all members to carry out their functions in the community as well. Besides, family ideally will provide satisfaction and an optimum condition that will provide one's prosperity in their life.

Furthermore, something parents should struggle for is their efforts to develop children as optimum as possible in their possibly various potentials. In this case, parents might give any blue print and of course later any freedom on how children's future will be initiated, how they can plan it, and how to be seriously responsible for what they take. However, providing freedom is critical for children as it is a determinative factor that differentiates human beings from other creatures. By doing all those things, it is expected that children can shape and develop every single potency they have [7].

\section{Research method}

In collecting the data, this study employed a survey as its technique of collection. The population in this study was students from $2^{\text {nd }}$ grade of SD Labschool FIP UMJ (Muhammadiyah University of Jakarta) and students from $2^{\text {nd }}$ grade of MI Madrasah Pembangunan UIN Jakarta. Determination of the sample in this study using claster random sampling technique. Data collection was carried out directly by the researcher using a questionnaire technique (questionnaire). Every child, assisted by parents or teachers to fill out a question item sheet. Instrument development is done by arranging indicator variables and instrument research grids, conducting trials, testing the validity and reliability of instruments. Data analysis was carried out including descriptive analysis and hypothesis testing. Data obtained from the results of the study were analyzed using descriptive and inferential statistical analysis which is often also called probability statistics.

\section{Discussion}

Based on the results of the analysis and testing of the hypothesis, it is shown that the four hypotheses proposed in this study are generally proven as having significant influence either partially or simultaneously. The details on that result are described as follows:

\subsection{Physical activities matter to social skill}

The first test shows that there is an effect of Physical Activity on Social Skills with a correlation coefficient of 0.342 and a regression coefficient of 0.569 . It surely means that there is a critical influence of physical activity on social skills.

Humans are basically social creatures. This idea can be fruitfully seen from the way they need a friendly attitude towards others, have a sense of sympathy, and also encourage empathy and desire for social acceptance. In contrast, there are significant differences shown by the pattern of children's life in today's era. Today's lifestyles are always preoccupied with their 
respective activities. For instance, they make playing Play Station, online games, Blackberry or the internet to become a daily habit which if not restricted in its use can affect their social life [8].

In the development of facilities and access that are all modern and technology based, not only adults can enjoy the convenience, but also the children. Those facilities such as play stations and online games already exist in various regions and can be accessed via the internet or mobile phones which are now owned by anyone. The impact of uncontrolled playing games will make children lose their time to socialize. This can cause the child to then become isolated from the association and their social skills become undeveloped. As well as the social sensitivity of the child will become low controlled due to the fact that playing games can make children lose time to socialize.

Furthermore, [9] in his research suggested that physical activity has an important contribution to social skills "Physical training and sports have crucial contributions in the development of both the social and motor skills of children.

\subsection{Socio economic factors mater to social skill}

Based on the results of testing the second hypothesis, it can be concluded that there is a socioeconomic influence on social skills with a correlation coefficient of 0.398 and a regression coefficient of 0.646. It indicates that Socio-Economic can give crucial influence on Social Skills. Human needs one another may not be the same and even vary. This is due to the different of socioeconomic status: some of those are with high socioeconomic status, and some are moderate and some others are relatively low. For those who are classified as high in their socioeconomic status, of course, will find that everything they need will be easily fulfilled in the form of clothing, food, housing, and especially education for their children.

Parents with a high socioeconomic status will have the opportunity or will have a wider opportunity to obtain all the needs that may not be obtained by parents with low socioeconomic status. With the fulfillment of all needs related to the improvement of children's social skills, those high-end children will be kindly facilitated to develop their talents and abilities to become better. But however, that kind of parents will experience a little stress and are more proactive in parenting techniques. In these conditions, the opportunity to increase social skills is greater by individuals who have parents with high socioeconomic status. [10] states "parents who have more advantageous socioeconomic backgrounds will experience less stress and employ more proactive parenting techniques".

There are several indicators that affect the socioeconomic status of parents, such as level of education, occupation, income level, or community prestige. Then, it can be said that the socio-economic status of parents is very influential in meeting the needs of family life. Parents whose socioeconomic status is sufficient enough tend to make it easier for their families to make ends meet. In terms of education, they can fulfill it without terrible economical obstacles. As the result, their children will optimally grow their effort to gain knowledge, appreciation and self-actualization.

\subsection{Family circumstances matter to social skill}

Family becomes ones' first and foremost environment where they can interact as the oldest educational institution. It means that family is the place where an educational process begins. 
For this reason, parents need to act as educators for their children as family environment is said as the most important environment, because it becomes the place where children spend their most time of day.

Conducive family will always maintain its harmony. In addition to children's' need, conducive family will provide greater attention to children's well-being as it will flow positive energy for their families and their environment, especially for children. That case is expected to make the children feel comfortable at home and always miss their parents' love. If children grow up in a conducive environment, the children are then easily be educated and be directed in every attitude and action. Successful initiative learning experiences will be successfully experienced by children at home. The home environment is fun, loving, and full of stimulation, which it will heighten the learning potential of children as they are stimulated to use their natural resources, namely the full five senses and surely it will increase their social skills. Conversely, if children grow up in a family environment that is not conducive with poor education and culture, their physical and mental development will be hampered. Their acquisition process of education will also be hampered, especially in the case of social skills development. If the home environment is chaotic, rigid, all restricted, cold, and without learning stimulation, children will not have the freedom to develop their learning potential optimally.

After fostering a conducive family environment, the duties and responsibilities of parents in meeting children's psychological needs will then be easier to conduct. Another advantage could gain is that the child's education process will be achieved optimally especially in improving children's social skills, "Family environment affects the social competence during a more crucial period in life [11].

\subsection{Physical activities, socio-economic and family environment jointly influence social skills}

Based on the results of testing the second hypothesis, we come to the conclusion that there is an influence of Physical activities, Socio-Economic and Family Environment on Social Skills with a correlation coefficient of 0.598 and a coefficient of determination of 0.358 . It means that all those things matter to foster children's social skill. Dealing with this case, social analysts believe that society is a structure consisting of families.

During this, children will obtain knowledge, values, attitudes and important behaviors needed for their future participation in society. In this case, family transforms as the most important part of the social network of children, as well as it becomes the first environment of children during the initial formative years to obtain early social experience which will determine their future social relations as citizens. Therefore, the family has a very large role in the process of children's social development, because it will determine whether the child is able to become a responsible citizen (as a social person) or even develop as a non-social and anti-social one that is disturbing and even harmful for the life of others.

Although the family environment is conducive and strongly supports the development of children's social skills, the internal factors of a child are very influential. Children who often perform physical activities will automatically often interact with the surrounding environment and will improve their social skills. 


\section{Conclusion}

In accordance with the result of statistical calculation and the analysis described above, it can surely lead to the following conclusions: 1) Physical activity contributes to a direct positive effect on social skills. This means that the more children doing physical activity, the more improvement on the social skill they could gain. 2) Social Economic factors matter on the development of social skill. By this means, the better socio economic status ones' parents have, the stronger the establishment a child could get for their social skills. 3) Family environment gives crucial effects on the foster of ones' social skills. The more conducive environment a family could draw, the better chances their children get to develop better social skills. 4) Physical activities, socioeconomic status, and family condition all at once will determine whether a child could get an optimum growth of social skills.

\section{References}

[1] A. Zurek, J. Torquati, and I. Acar, "Scaffolding as a Tool for Environmental Education in Early Childhood.," Int. J. Early Child. Environ. Educ., vol. 2, no. 1, pp. 27-57, 2014.

[2] Q. Suleman, I. Hussain, and Z.- Nisa, "Effects of Parental Socioeconomic Status on the Academic Achievement of Secondary School Students in District Karak (Pakistan)," Int. J. Hum. Resour. Stud., vol. 2, no. 4, p. 14, 2014.

[3] A. Zsolnai and L. Kasik, "Functioning of social skills from middle childhood to early adolescence in Hungary,” Int. J. Emot. Educ., vol. 6, no. 2, pp. 54-68, 2014.

[4] P. A. PERDANI, "Peningkatan Keterampilan Sosial Anak Melalui Permainan Tradisional," J. Pendidik. Usia Dini, vol. 8, no. 1, pp. 129-136, 2014.

[5] E. B. Hurlock, "Perkembangan Anak Jilid 1 Edisi keenam terjemahan Meitasari Tjandrasa dan Muslichah Zarkasih," Jakarta: Erlangga, 1978.

[6] D. F. W. Permana, "Perkembangan Keseimbangan pada Anak Usia 7 s/d 12 Tahun Ditinjau dari Jenis Kelamin," Media Ilmu Keolahragaan Indones., vol. 3, no. 1, 2013.

[7] H. Kotaman, "Freedom and child rearing: Critic of parenting practices from a new perspective," Procedia-Social Behav. Sci., vol. 82, pp. 39-50, 2013.

[8] K. Achroni, "Mengoptimalkan tumbuh kembang anak melalui permainan tradisional." Jogjakarta: Javalitera, 2012.

[9] A. Ozyurek, I. Ozkan, Z. Begde, and N. F. Yavuz, "Effects of Physical Training on Social Skill Levels of Preschool Children," J. Sport. Sci., vol. 3, pp. 282-289, 2015.

[10] S. Arif and G. Albulene, "The relation between socio-economic status (SES) and early development: empirical findings and theoretical perspectives," 2017.

[11] C. V Pardhasaradhi and V. Goel, "International Journal of Applied And Pure Science and Agriculture." 